\title{
Democratic Individualism, Expertise, and the Public Interest: The Legacy of the Commonwealth Conference
}

\author{
Stanley R. Ridgeway
}

PUBLIC POLICY PLANNERS in twentieth-century America have faced a persistent dilemma: how to reconcile the commitment to free-market individualism with a modern state's need for management and planning in the public interest. Although this tension became particularly acute in the wake of New Deal measures, scholars have recently traced its roots to the New Era of the 1920 s. $^{1}$ One solution proposed during the New Era was the application of expertise to matters of public policy. The nonpartisan methods of social science, proponents argued, would yield policies that would minimize conflicts among individuals, organizations, and the state. This argument was a common one at the Commonwealth Conference, a forum for social scientists that

1. Ellis W. Hawley, Herbert Hoover as Secretary of Commerce, 1921-1928 (lowa City, 1981) is a good guide to New Era historiography. The 1920s have been depicted variously as an "era of wonderful nonsense," an age of business reaction, and part of an ongoing impulse towards liberal reform. See Frederick L. Allen, Only Yesterday (New York, 1932); Clarke A. Chambers, Seedtime of Reform (Minneapolis, 1963); Ellis W. Hawley, The Great War and the Search for a Modern Order (New York, 1979); idem, "Herbert Hoover and American Corporatism, 1929-1933," in Martin L. Fausold and George T. Mazuzan, eds., The Hoover Presidency (New York, 1974); John D. Hicks, Republican Ascendancy, 1921-1933 (New York, 1960); Richard Hofstadter, The Age of Reform (New York, 1951); William E. Leuchtenberg, The Perils of Prosperity, 1914-1932 (Chicago, 1958); William A. Williams, The Contours of American History (Cleveland, 1961); idem, "What This County Needs ..." New York Review of Books, 5 November 1970; Joan Hoff Wilson, Herbert Hoover: Forgotten Progressive (Boston, 1975).

THE ANNALS OF IOWA 50 (Spring 1990). (C) The State Historical Society of lowa, 1990. 
met annually in Iowa City from 1923 to 1930, except in 1929. A look at the conference sheds light on the institutions and ideology involved in efforts to apply the principles of scientific management to the problems of the modern state. ${ }^{2}$

New Era social scientists believed that through a mixture of institutional reform, elite direction, and public participation America's economic, political, and social order could be reformed, and they were convinced that they could contribute to that end. They never succeeded in finding a way to ensure the preservation of a political system based on individual autonomy and mobility while at the same time supplying the expertise to make capitalism more humane and productive. Nevertheless, their efforts to do so helped to shape American institutional development. New Era endeavors such as the Commonwealth Conference marked the beginnings of the existing system of nonpartisan "think tanks" and research organizations - those in the private sector as well as those affiliated with government and universities - that have sought to meet the need for expertise while preserving an individualistic creed.

THE CAREER of Benjamin F. Shambaugh, the Commonwealth Conference's prime mover, was intimately connected with the ascendant social science movement of the early twentieth century. Influenced by Progressive history and the "New History" of James Harvey Robinson, Shambaugh came to believe that scholarship should discover and use the lessons of the past to reduce the problems of the present and shape a more harmonious future. His work for the Committee on Public Information during World War I increased his confidence in social science methodology as a means to resolve social problems.

Shambaugh had earned his M.A. from the University of Iowa in 1893 and had studied at the Wharton School of Finance under James Harvey Robinson. Returning to the University of Iowa in 1896, he brought with him a conviction that "sound

2. This article complements such recent works as Guy Alchon, The Invisible Hand of Planning: Capitalism, Social Science, and the State in the 1920s (Princeton, NJ, 1985); and Donald T. Critchlow, The Brookings Institution, 19161952: Expertise and the Public Interest in a Democratic Society (DeKalb. IL, 1985). 
political philosophy [should be] based upon legitimate scientific and historical data." In 1900 the University of Iowa established a School of Political and Social Science; two years later, Shambaugh became its chairman. In the same year he was a founding member of the American Political Science Association; later he served on the board of editors of the American Political Science Review, and became president of the organization in 1929. In the historical field, he helped to organize the Mississippi Valley Historical Association and served on the board of editors of the Mississippi Valley Historical Review. ${ }^{3}$

Shambaugh was also superintendent of the State Historical Society of lowa. In that capacity he edited the six-volume $A p$ plied History series that appeared from 1912 to 1930 . Applied History covered "such classic Progressive topics as the regulation of public utilities, primary election laws and child labor legislation." It was "not aimed at the scholarly community," but was "intended for use by state legislators and citizens." 4 The introduction to volume one, written by Shambaugh, proposed the "use of the scientific knowledge of history and experience in efforts to solve present problems." This goal required thorough, impartial, accurate, and scientific gathering of data, "expert" interpretation of the facts, "expert" framing of legislation, and "expert" administration; in short, "it frankly recognizes the fact that public service to be efficient must be guided by open-minded experts." 5 Shambaugh believed that "the need of trained experts for public service [had] never been greater than at the present time" and that more would be needed in the future. ${ }^{6}$

In Shambaugh's view, though, efficient government not only

3. Benjamin F. Shambaugh (hereafter cited as BFS), "Politics and Philosophy," manuscript for speech delivered at Political Science Club, Iowa City, Iowa, 30 August 1899, 22-23, in Politics and Philosophy file, box 10, folder 14, Shambaugh Family Papers, University of Iowa Archives; Jacob A. Swisher, rough draft of unpublished biography of BFS, chap. 9, p. 7, in Shambaugh NotesCommonwealth Conference file (hereafter cited, CC), Jacob A. Swisher Papers, MS 93, box 7, State Historical Society of Iowa, Iowa City (hereafter cited as SHSI).

4. Alan M. Schroder, "Applied History: An Early Form of Public History," Public Works Historical Society Newsletter, March 1980, 3.

5. BFS, ed., Applied History, 6 vols. (Iowa City, 1912-1930), 1: vii-ix.

6. BFS, "Training For Public Service," undated, unpublished manuscript, 1, in Training for Public Service file, box 3, folder 7, Shambaugh Family Papers. 
required expertise but also demanded socially aware citizenvoters. Shambaugh assumed that an enlightened electorate was the basis of good government. An enlightened electorate, for Shambaugh, would be "filled with the ideal that they are not independent, isolated individuals, but members of a larger whole - the family, the community, the city [and] the nation."7 This conviction was rooted in the central political ethos of the Early Republic, which held that in America a harmony of interests could emerge from the interaction of autonomous individuals who had political influence and economic mobility. This conception shaped American political mythology and was so satisfying that few of its adherents realized that it was a dubious proposition. Its implied theory of a nation of free and equal individuals has survived to the present day. Yet in Shambaugh's time it appeared to many that the notion was beginning to crumble under the pressures of corporate growth, urbanization, and racial, ethnic, and class conflict.

Indeed, the idea that political and economic competition was the best way to promote the public interest had always been internally contradictory. As its inconsistencies became more evident, academicians like Shambaugh were among those who sought to reconcile the individual's pursuit of self-interest with the state's pursuit of the public welfare. New Era social scientists were seeking to answer a long-standing and fundamental question: what was the proper balance between individualism and planning for the public interest in a modern state?

THE COMMONWEALTH CONFERENCE was part of a national movement that sought to resolve this dilemma. Through similar conferences, such as the Institute of Politics at Williamstown and the Institute of Public Affairs at the University of Virginia; through organizations such as the Brookings Institution and the Social Science Research Council; and through advisory committees such as President Hoover's Commission on Recent Social Trends, New Era academicians were carving out a niche for themselves in the policy-making process.

7. BFS, "The Teaching of Civics in the Public Schools," unpublished manuscript, 1-2, in Training for Public Service file, box 3, folder 6. Shambaugh Family Papers. 
The first Commonwealth Conference, in 1923, was primarily a local affair. The following year Shambaugh assumed control of the forum and began to transform it into a prestigious annual event. A wide range of issues, including "Problems of the Electorate," "State Universities and the State," and "Municipal Government and Administration," was discussed. By 1925 the conference was being covered in the Chicago Tribune, The Nation, and the New York Times.

This national interest, which helped establish the University of lowa as a leader in the applied social science movement, was in part due to the caliber of the participants. Among those who attended were Charles A. Beard, the great Progressive historian; Isador Lubin, an economist who had worked for the War Industries Board and the Brookings Institution; Charles E. Merriam, founder of the Social Science Research Council; and Raymond Moley, professor of government at Columbia University, who in the 1930 s would play a prominent role in Franklin D. Roosevelt's "Brains Trust:"8 A few politicians and members of the press participated in the conferences. Among them were lowa Congressman L. J. Dickinson; Henry A. Wallace, editor of Wallaces' Farmer; Ernest Gruening, former editor of The Nation; and Bruce Bliven, lowa native and editor of the New Republic. But the Commonwealth Conference was primarily a forum for social scientists, and especially for political scientists.

We do not have extensive records of what was said at the Commonwealth Conferences, but the surviving documents do allow us to gain some sense of what New Era social scientists were proposing as mechanisms to preserve individualism while allowing the state to promote the public interest through planning. The surviving speeches reveal that the conferees agreed on some points and divided on others. They agreed that free-market individualism should be merged with some government regulation of the activities of individuals and corporations. They also believed that government should be made more efficient so that it would better serve the public interest. And they were convinced that academia should be at the heart of reform, since it was best suited to train competent administrators and judicious citizens.

8. Jacob A. Swisher, rough draft of unpublished biography of BFS, chap. 12, pp. 1, 6-9, 12-13. 
From this shared ground, the academicians diverged in emphasis. They offered various plans for reconciling individual rights with the needs of the group. Some stressed the scientific gathering of data, national planning, and the restructuring of governmental institutions. Some distrusted the masses and placed their faith in expertise almost exclusively, while others thought that widespread political participation was essential to sound government. Yet others leaned toward corporatist, or functional group, representation. Most of the conferees did not fall strictly into one of the schools of thought but proposed a blend of planning, expertise, structural reform, and education of the public.

That their ideas are not easily classified reflects the difficulty they had in determining the proper relationship between individual freedom and the public interest. It was an age-old problem that seemed particulary acute in the early twentieth century due to the growth of conflicts between individuals and interest groups in an emerging urban-industrial order. Many social scientists thought that their knowledge and methods were the key to resolving the dilemma. Looking back, we can see that they were overconfident. New Era social scientists did not have the benefit of hindsight, however. Their proposals were sincere efforts to improve the quality of national life while at the same time preserving American individualism.

One of the few politicians to address the topic of how individualism could be preserved in the midst of expanding government activity was Iowa's former governor and current senator Albert Baird Cummins. Addressing the conference in 1925 on the relationship between the federal government and the states, he stressed the need to reorganize, rather than to eliminate, the governmental bureaucracy. Cummins denied that the numerous "departments, bureaus, commissions [and] boards" in existence had established an "unnecessary supervision over the lives, affairs and conduct of the individual," and he maintained that organizations such as the Railroad Labor Board were an integral part of "the wisest and best government in all the world" and had played a significant role in making "the people of this country . . the happiest, most fortunate people upon the face of the earth." The principal problem with such institutions, he said, was that "incompetency and inefficiency" existed "in every department, com- 
mission, bureau and board, 1 and must be removed. ${ }^{9}$ Cummins's viewpoint was shared by most progressive social scientists. As a rule, they saw planning boards, expertise, and an administrative apparatus as inevitable. They generally did not treat the bureaucracy as an imposition but sought to ensure that it was efficiently organized so as to bring benefits to all while avoiding unnecessary impositions on individual freedom.

Professor Francis W. Coker, who like a number of conferees had studied with James Harvey Robinson at Columbia, also dealt with the problem of governmental restrictions in a nation that venerated individual self-reliance. His opinion was similar to that of Senator Cummins: since government was bound to have some impact on citizens' lives, it was better to reorganize the state's "restrictions and services" than it was to diminish the state's power. Indeed, in Coker's view, complete individual freedom and a totally unrestricted market had never existed in America. "From the very beginning of our national government," he said, "freedom of competition, or exchange, [and] of labor" had been subject to governmental control. To be sure, Americans were individualistic, but they were also "collectivistic." Disagreements concerning the state's actions were not arguments "between those who want more government activity and those who demand less"; rather, they were disputes "between those who want less government regulation here and more there." Like Cummins, Coker assumed that government machinery could not and should not be dismantled; therefore it should be restructured so that it would operate smoothly for the public welfare. ${ }^{10}$

Cummins and Coker argued for efficient state institutions, but said little about the relative importance of leaders and the populace. Other conferees were more explicit on that point. Frank Loesch, for example, who was a member of the National Commission on Law Observance and Enforcement, believed that "men of character" should set public policy, and that the privilege of voting should be reserved for "the educated and cultured."11

9. Senator A. B. Cummins, "The Relation of the Federal Government to the States," manuscript for speech delivered 1 July 1925, 6, in Third CC file, CC Papers.

10. Press release, 29 June 1925, in Third CC file, CC Papers.

11. Frank Loesch, transcript of speech delivered 30 June 1930, 16, in Seventh CC file, box 5, CC Papers. 
Another adherent of government by "the educated and cultured" was William Bennet Munro, professor of American history and government at Harvard and president of the American Political Science Association in 1927, the year he spoke at the Commonwealth Conference. According to Munro, "It is a pity that we do not have an effective way of concealing the fact that an election is to take place from many who now participate. We should encourage the moron vote to stay at home. ${ }^{112}$

One month later, Munro elaborated on his autocratic notions in an article published in the Yale Review. "Some races [had] more political genius than others," he claimed, and within races some individuals were superior to their fellows. Therefore, if democracy were pressed to its logical conclusion of "government by the multitude," the result would be "anarchy." Recent trends toward "giving votes to everybody, without distinction of race, color, sex, or intelligence," then, were misguided. After all, most voters were more likely to know "what the Andy Gump family did a little while ago than what happened to the McNary-Haugen Bill." Already, Munro estimated, 20 percent of voters had "no business" taking part in elections. To make matters worse, the "subnormal" sector of the population was reproducing at a far greater rate than the more intelligent elements, thus further undermining the electorate's chances of choosing wise leadership. To remedy the situation, Munro proposed that the electorate be "trimmed at the edges"; voters should be required to take an I.Q. test that "anybody above the grade of moron" could pass. ${ }^{13}$

While Loesch and Munro were frankly elitist, many of their colleagues were more ambivalent about how to balance expertise, democratic individualism, and state planning. Their proposals for reform involved a blend of elite direction, civic education, and institutional reorganization. One such conferee was Charles E. Merriam. As the director of the University of Chicago's political science department he was at the forefront of "an American social science which had as its ultimate goal the direct

12. In Press Materials and Papers file, box 3, CC Papers.

13. William Bennet Munro, "Modern Science and Politics," Yale Review 16 (July 1927), 728; idem, "Intelligence Tests for Voters," The Forum 80 (December 1928), 823-28. 
application of scientific knowledge to social problems." Merriam proposed a mixture of scientific methods and civic education as the means to revitalize American politics. ${ }^{14}$ By "scientific methods" he meant "the reorganization of the registration system" and other structural changes that would facilitate voting. More important than structural reform, however, was "the necessity of affecting in some favorable way the attitude of the non-voter. ${ }^{15}$ Like Cummins and Coker, Merriam supported institutional reform. But quite unlike Loesch and Munro, he believed that a sound American political system required more citizen participation, not less.

Benjamin F. Shambaugh's outlook was similar to Merriam's. He assumed that social scientists could provide a valuable public service by gathering data that could be the basis for policy making. Their more crucial role, however, was to educate the voter. As Shambaugh put it, "the real meaning of the American Commonwealth is [not] to be found in statistical atlases" but in the "intellectual and spiritual purpose of the electorate" without which democracy would fail. ${ }^{16}$ His emphasis on the electorate as "the fundamental department of government" put him at odds with colleagues such as William Bennet Munro. Shambaugh had little sympathy for the "intelligence testers [who] would segregate the geniuses from the dumb-bells and vocationalize the citizenry on the basis of I.Q.'s." 17 In contrast to Munro, who believed that the public interest could be best served by excluding the uninformed masses from political affairs, Shambaugh was confident that the electorate and expert administrators could work together to overcome the problems posed by capitalist and urban expansion. He emphasized the university as the institution that could make the partnership work by educating a responsible electorate and expert administrators.

Like Merriam and Shambaugh, Charles A. Beard fell in the

14. Barry D. Karl, foreword, 1, in Charles E. Merriam, New Aspects of Politics, 3d ed. (Chicago, 1970). The book was first published in 1925.

15. Charles E. Merriam and Harold F. Gosnell, Non-Voting: Causes and Methods of Control (Chicago, 1924), 248-49.

16. BFS, "The Problem of the Voter," manuscript for radio broadcast delivered in Iowa City, Iowa, 20 June 1924, 4-5, in Radio Talk File, box 10, folder 25, Shambaugh Family Papers.

17. Press release, 29 June 1925, 1-2, in Third CC file, CC Papers. 
middle of a range between autocracy and democracy. Beard was president of the American Political Science Association when he spoke at the conference in 1926 . He advocated the establishment of "a great national committee" composed of "individuals who have given some thought and study to the subject" of governmental organization. The committee would function as a citizens' lobby to promote free speech and monitor governmental activities. It would include many academics - "bold thinkers" whose ideas were "hooted at by the mass" but who were the source of "all great improvements in government and society. ${ }^{18}$ Yet Beard was not strictly elitist. According to his biographer, he had long emphasized accountability to the public because he "saw a danger to democracy stemming from [an] emphasis on expertise."19 Thus he had more in common with his colleagues Merriam and Shambaugh, who favored a blend of expert direction and civic responsibility, than with the elitist Munro. For Beard, as for Merriam and Shambaugh, academics were crucial in such a scheme because educators could best train efficient administrators and socially conscious citizens.

To Glenn Frank, who at the time of his appearance at the conference in 1925 was preparing to accept the presidency of the University of Wisconsin, education was also a key element in resolving the tension between unrestrained individualism and planning for the public interest. He was more elitist than Merriam, Shambaugh, or Beard, but he should not be classified as an exponent of autocracy. Rather, his ideas reflect the wide range of proposals made by New Era educators. In his plans, a socially aware business community replaced an enlightened electorate as the ally of university-trained administrators. In a number of books, such as The Politics of Industry (1919), Frank had argued that if corporate leaders voluntarily cooperated with labor, then the class struggle of the "old capitalism" would decline and be replaced by a new, more rational capitalism. Frank also believed that the political order needed restructuring. Traditional representative government, he thought, should be discarded in favor of "occupa-

18. Charles A. Beard, atranscript of speech delivered 29 June 1926, 11-16, in Fourth CC file, CC Papers.

19. Ellen Nore, Charles A. Beard: An Intellectual Biography (Carbondale, IL, 1983), 45. 
tional and group representation" carried out by the expert hand of "unofficial statesmen." No institution was better suited than a state university to train these expert administrators. Thus, for him as for his colleagues, education was of fundamental importance: it could train the experts who would represent functional blocs and seek harmony among the competing interest groups that made up American society. The result, he hoped, would be an "industrial democracy" in which individual initiative was preserved while social conflict was diminished. ${ }^{20}$

Frank's plan faced an obstacle, however: "democracies [had] always been a bit suspicious of their experts" and throughout history had been hostile to those who thought differently. Faced, like Beard, with the dilemma of finding a place for expertise in a democratic society, Frank determined that "the man of superior knowledge" should offer "his power to the service of the majority in an utterly disinterested fashion."21 Frank, then, assumed that expertise need pose no threat to democracy - and indeed was fundamental to a vital "industrial democracy" - as long as it was nonpartisan. Presumably, universities that trained "unofficial statesmen" would emphasize nonpartisanship. Although he was more elitist than most of his colleagues, Frank's program of corporate responsibility, political reorganization, and elite guidance, like their proposals for reform, relied heavily on education.

This faith in education united the participants in the Commonwealth Conferences, even though their plans for reform differed in emphasis. Although some conferees stressed the need to reorganize governmental institutions, while others emphasized expertise, and yet others argued for the importance of an enlightened public or business community - or for some combination of these reforms - all of their plans were built upon the foundation provided by education. From education, they believed, could emerge a creative elite, a group of trained, objective administrators, a socially aware corporate leadership, and a civic-minded public. Since no one was better suited than an academic to provide education, we can conclude that the conferees

20. Glenn Frank, transcript of speech delivered 1 July 1925, 4-8, in Third CC file, CC Papers.

21. Ibid. 
saw themselves and their disciplines as essential in resolving the tension between an individualistic political philosophy and the needs of a modern state for planning in the public interest.

THE SOCIAL SCIENTISTS involved in the Commonwealth Conference hoped that they could furnish the education and methodology that would enable the United States to surmount the social tensions inherent in urban-industrial expansion, but the application of their educational skills would be a gradual process, and after the advent of the Great Depression it appeared to many analysts that more drastic measures were needed. Consequently, national economic planning increased rapidly following 1930, continuing a trend that had begun during the Hoover administration of greater reliance on expert advisory bodies such as the Committee on Recent Economic Changes. As expert commissions and planning agencies multiplied in the 1930s, many conference participants, such as Raymond Moley, Isador Lubin, and Charles E. Merriam, obtained positions as "unofficial statesmen" in an expanding bureaucracy.22 Other conferees continued to grapple with the problem they had confronted at the Commonwealth Conference: what was the best mechanism to reconcile expert planning with individualism to promote the public good?

As Charles A. Beard, Glenn Frank, and Benjamin F. Shambaugh, among others, found, the answer to this riddle remained as elusive in the 1930s as it had been in the 1920s. Beard argued that both an unrestricted free market and a state-directed economy were dangerous extremes. He believed that a "middle way" should be found between the two. But how? Beard rejected many of the answers that had been offered at the Commonwealth Conference: he considered the scientific method insufficient; he thought government by experts was a "fascist" doctrine; he believed that education of the electorate could be only a partial answer; and he thought that corporatist arrangements would be "likely to fall apart from violent differences of opinion" among functional group leaders. In Beard's view, America needed some expert input into policy making, but it must not neglect individ-

22. Paul B. Cook, Academicians in Govermment from Roosevelt to Roosevelt (New York, 1982), 50-52. Under FDR, Lubin was Commissioner of Labor Statistics; Merriam was a member of FDR's National Planning Board. 
ual initiative. He believed expertise and individualism could coexist if large corporations were joined in a National Economic Council that would coordinate the firms' activities and transform them into "national public service enterprises." As such, large business concerns would continue to seek profit; at the same time, the council would ensure that their operations served the public interest. The inconsistencies in Beard's proposal reflected the depth of the dilemma he confronted. Somewhat naively, he assumed that large business concerns would accept coordination through a National Economic Council that would somehow reconcile the profit motive and the public interest. And he did not explain how a council that would employ numerous experts would avoid being "fascist." 23

Glenn Frank's reasoning was similar to Beard's. He advocated the creation of "an integrated national organization" of business leaders through which they could exercise "responsible self-government." Unfortunately, Frank's scheme was as flawed as Beard's, for he assumed, like Beard, that corporate leaders many of whom at the time were cutting wages and reducing payrolls in order to maximize profits - would willingly become public servants. ${ }^{24}$

Benjamin F. Shambaugh's proposals for charting a course between individualism and collectivism did not involve such a national coordinating agency. Instead, he continued to place his hopes in a socially conscious and politically active electorate. This theme surfaced in several of his talks during the 1930s. In "When the Dictator Comes," Shambaugh called attention to two conflicting philosophies: one, which he linked with Herbert Hoover, emphasized "individual initiative, individual self-interest ... [ [and] the profit-economy"; the other, which he associated with Franklin D. Roosevelt, involved a modern collective state and its "wide range of governmental control and regulation." He feared that in the shift from one system to the other, nineteenthcentury democracy, in which the many ruled, might give way to

23. Charles S. Beard, "Government by Technologists," New Republic 42 (18 June 1930), 118-19; idem, "A Five-Year Plan for America," The Forum 86 (July 1931), 4-11.

24. Glenn Frank, "If I Were Dictator," The Nation 133 (23 December 1931), 689-90. 
"government by the few, the elect." Shambaugh advocated merging the two philosophies to create a concept of citizenship in which individuals would pursue their self-interest by basing their actions on what was best for the community. Although he believed that expert analysis of data and expert framing of policy were essential to the reform process, he also was convinced that "journeying laboriously" through masses of data was not enough. He envisioned something more: "a state that was based upon moral and spiritual values" and was bound by "a set of human obligations."25 He hoped that a reciprocal social order would preserve individual freedom even while the state was increasingly turning to expertise.

At first glance, Shambaugh's views may appear less problematic than those of Beard and Frank. Yet Shambaugh looked back to an order that supposedly had prevailed in nineteenthcentury America, one that was rural, communitarian, and based on a Christian "brotherhood of man." In looking to the previous century for his solution, he confronted the same paradox that had plagued political philosophers of that era: how could the reciprocal and egalitarian tenets of Christianity and the Enlightenment be reconciled with the competetive, acquisitive, and materialistic character of capitalism? How was the individual's pursuit of happiness to be reconciled with the public interest? Nineteenthcentury thinkers never resolved the problem, and neither did Shambaugh. Nor did his contemporaries or successors. The continuing tension between individual liberty and planning for the public good testifies to the depth of the dilemma.

THE MOVEMENT of which the Commonwealth Conference was a part achieved mixed results. The New Era social science movement succeeded in helping academicians gain positions in an expanding technocracy, and it succeeded in altering the course of American institutional development. When New Deal policymakers confronted rising unemployment, corporate consolidation, and urban tensions, the social scientists' claims concerning nonpartisan expertise and scientific management, as expressed at

25. BFS, "When the Dictator Comes," manuscript for speech delivered at the School of Citizenship, Des Moines, Iowa, 19 November 1933, 1-9, in When the Dictator Comes file, box 11, folder 11, Shambaugh Family Papers. 
forums such as the Commonwealth Conference, began to look like a reasonable option. And as academicians increasingly entered government, the institutional base of the American political system was restructured. As a legacy of the Commonwealth Conference and related New Era activities, a network of "think tanks," such as the Brookings Institution, the Heritage Foundation, and the Rand Corporation, now gather data and offer expert commentary on public policy.

The New Era social science movement also shaped the course of university development. Rendering service to taxpayers has always been a central purpose of state-sponsored universities, but undertakings such as the Commonwealth Conference stimulated the tendency. Since the 1920s, the desire for expert analysis of social problems and the policy-making process has led to the creation of many organizations and institutions in academia, such as the Bureau of Government Research at the University of Kansas, the Humphrey Institute of Public Affairs at the University of Minnesota, the Institute of Government at the University of North Carolina, and the Institute for Social Research at the University of Michigan.

The University of Iowa's Institute of Public Affairs, which began operation in 1949, had a similar function. Like the Commonwealth Conference, it was part of a long tradition of serviceoriented scholarship at the university. In 1933 a Brookings Institution survey commented on the University of lowa's "capacity to render notable public service," and said that "probably no State university [had] served its constituents in a more comprehensive, persevering and practical manner. ${ }^{26} \mathrm{Ph} . \mathrm{D}$. dissertations in political science maintained an emphasis on state and local government and administration for twenty years after the last conference, and in the 1950s the school began to train city managers. Shortly thereafter the university created a School of Urban and Regional Planning. Besides training specialists, the university also engaged in educating well-rounded citizens through the General Educational Requirement system. Conceived after World War II, that system was an offshoot of Shambaugh's "Campus Course."

26. The Brookings Institution, A Report on a Survey of Administration in Iowa (Des Moines, 1933), 213, 598. 
The multiplication of think tanks and university research organizations and the spread of academic programs designed to educate governmental experts and civic-minded citizens reveal that many of the proposals suggested by New Era social scientists at forums such as the Commonwealth Conference were adopted in the succeeding years. In that sense the academics achieved their goal. Yet in another sense they failed to realize their aspirations.

New Era social scientists never succeeded in finding a mechanism to integrate expertise into a democratic system in such a way as to promote the public welfare. We should not denigrate their efforts, because no generation since has surpassed their achievements. But we can try to understand why their plans have not resulted in a more vital and efficient American political system. Much of the answer can be traced to their flawed assumptions. For example, New Era social scientists posited a "public interest" that could be identified and served. In doing so, they underestimated the bitterness of racial, ethnic, and class conflict in America. Perhaps this was because they were convinced that in a democracy, and perhaps especially in America's democracy, problems would lend themselves to efficient and fairly rapid solutions, and that therefore conflicts among agriculture, labor, business, and the state, and between experts and the masses, could be overcome in the name of the "public interest." Supporting this illusion was the belief that experts such as themselves could act in a disinterested and scientific manner when providing the data, methodology, policy recommendations, and education that would bring together all the conflicting sectors of American society. This was the most crucial flaw in their assumptions and proposals. One must conclude that they were expecting too much of themselves, of their methods, and of the individuals and institutions that made up the American state. 
Copyright of Annals of Iowa is the property of State of Iowa, by \& through the State Historical Society of Iowa and its content may not be copied or emailed to multiple sites or posted to a listserv without the copyright holder's express written permission. However, users may print, download, or email articles for individual use. 